\title{
ARTIGOS \\ O DIÁRIO DE AULA COMO INSTRUMENTO DE REFLEXÃO NA FORMAÇÃO INICIAL DE PROFESSORES DE CIÊNCIAS BIOLÓGICAS
}

Glaucia Britto Barreiros Dulcinéia Ester Pagani Gianotto

\begin{abstract}
RESUMO: As experiências na formação inicial norteiam a construção do futuro docente. A prática do estágio é de extrema importância para apresentar os dilemas a serem enfrentados no exercício profissional dos licenciandos. Para desenvolver experiências práticas reflexivas, alternativas como a do Programa Institucional de Bolsa de Iniciação à Docência (PIBID) foram propostas. Nesse sentido, este artigo apresenta parte de uma pesquisa de mestrado que, entre outros fatores, buscou analisar as contribuições da utilização do instrumento pedagógico diário de aula para a reflexão da prática no ensino de Biologia, e que tem por objetivo investigar os 19 participantes do PIBID Biologia da Universidade Estadual de Maringá (UEM), identificando nas narrativas dos participantes aspectos relevantes. Com um enfoque qualitativo de natureza interpretativa e tendo a abordagem reflexiva como principal referencial teórico, pretendeu-se investigar como a ferramenta diário de aula influencia os processos que envolvem a formação inicial de Biologia. Com a análise, pode-se considerar que o diário é potencialmente significativo para o acervo histórico da prática vivenciada, o que contribui para o início de uma atitude reflexiva na formação inicial.
\end{abstract}

PALAVRAS-CHAVE: Professor reflexivo; Formação inicial; Diário de aula.

\section{Abstract}

The experiences in the initial training guide the development of future teachers. The practice stage is extremely important to introduce to undergraduate students the dilemmas which they will be facing during their future activities. To develop a reflexive practical experience, alternatives such as the Initiation Scholarship Program for Teaching (PIBID) were proposed. In this context, this article presents a section of a master's research, in which, among other factors, we sought to analyze the contribution of the use of the class dairy into the practice of reflection in the teaching of biology, aiming to investigate 19 participants of the PIBID Biology of Universidade Estadual de Maringá (UEM), identifying the relevant aspects in the narratives of the participants. Performing a qualitative interpretation approach, and having the reflexive approach as the main theoretical framework, we intended to investigate how the class diary influences the processes involved in the initial formation of the Biology teacher. With the analysis, it can be considered that the diaries a potential significant tool for recording the experienced practice, which contributes for an emerging reflexive attitude in the initial training.

KEYWORDS: Initial teacher's training; Reflexive professional; Daily classroom. 


\section{INTRODUÇÃO}

A compreensão das metodologias de ensino e a oportunidade de refletir sobre a prática docente, ainda na formação inicial, constitui a base para as escolhas didáticas do futuro professor e o estimula a criar propostas dinâmicas em sala de aula. Entretanto, o modelo atual de formação e o contexto da disciplina do Estágio Supervisionado (ES) são insuficientes para transformar o processo de ensino-aprendizagem desses licenciandos para uma prática docente reflexiva (PIMENTA; GHEDIN, 2002; SCHÖN, 2000).

Visando atender essa lacuna, novas propostas vêm sendo implementadas atualmente pelo governo brasileiro, como o Programa Institucional de Bolsa de Iniciação à Docência (PIBID), desenvolvido pelas Instituições de Ensino Superior (IES), vigente desde 2007. Primeiramente implementado nas instituições federais (2007), e em seguida nas estaduais (2009), o PIBID apresentou-se como uma proposta integradora de conhecimentos de dois diferentes contextos - a escola básica e a universidade (BRASIL, 2007). Na mesma perspectiva que o estágio supervisionado, porém sem o caráter disciplinar, o programa busca um compartilhamento, com os alunos, de saberes dos professores da escola básica e de suas experiências em sala de aula; dos professores das licenciaturas e de seus conhecimentos em pesquisa e formação de professores; e a criatividade e busca por aperfeiçoamento dos licenciandos e futuros professores. Desse modo, configura-se como um estágio mais autônomo e com perfil dinâmico.

No que tange aos pressupostos para a formação de professores, destacam-se as ideias de Nóvoa (1992), Schön (2000), Freitas e Villani (2002), Pimenta e Ghedin (2002), que defendem a construção de um modelo de formação profissional baseado na epistemologia da prática crítico-reflexiva. Uma maneira de incentivar o refletir sobre a prática, primeiramente pela escrita e posteriormente pela reflexão fundamentada (ZEICHNER, 2008), o diário de aula é utilizado e endossado por diversos autores (PORLÁN; MARTÍN, 1991; LIBERARI, 1999; GALIAZZI; LINDEMANN, 2003; PIETRO, 2003; PANIZ, 2007; GIANOTTO, 2008a; GIANOTTO; CARVALHO, 2015; BARREIROS; GIANOTTO, 2014; BARREIROS, 2015). Trata-se de um recurso pedagógico que, por meio de narrativas, influência de modo subjetivo (positiva ou negativamente) a reflexão da prática docente.

Nesse sentido, a presente pesquisa delineou-se em identificar se o diário de aula é um recurso pedagógico eficiente para ser utilizado na formação inicial crítico-reflexiva de professores de Biologia. A partir desse questionamento, o artigo discute os resultados de uma investigação sobre as contribuições do diário de aula na formação docente de acadêmicos de Ciências Biológicas da Universidade Estadual de Maringá (UEM) durante o desenvolvimento das atividades do PIBID Biologia, em 2013, que ocorreram no ensino médio (EM) de duas escolas públicas da cidade de Maringá (Paraná).

\section{FUNDAMENTAÇÃO TEÓRICA}

As tendências para a formação de professores são estimuladas pelo contexto socioeconômico e cultural do momento histórico em que se inserem. Retomando o contexto histórico da formação de professores no Brasil, observa-se que houve pouco estímulo e valorização da profissionalização docente. Ao longo do tempo, a maioria das políticas públicas estimulou apenas medidas paliativas (PIMENTA; GHEDIN, 2002).

Nas décadas de 1960 e 1970, por exemplo, havia a valorização dos aspectos didáticos e metodológicos relacionados às tecnologias de ensino, passando em um segundo plano para o domínio dos conteúdos (saberes específicos). Já nos anos 1980, o discurso educacional foi dominado pela dimensão sociopolítica ideológica da prática pedagógica (NUNES, 2001). Nesse período da formação de professores, as medidas pautavam-se 


\section{autêntica}

no modelo da racionalidade técnica, que concebia o professor como um mero aplicador de técnicas e de recursos didáticos. Para Tardif (2002), o professor era considerado um "idiota cognitivo". Nesses moldes, pouco foi realizado para sua formação efetiva, e nada que estimulasse uma reflexão nesse processo de formação, que também se apresentava descontextualizado e nos padrões tradicionais. Todo processo de aprendizagem deve ser composto por reflexões e, corroborando isso, Tardif (2002, p. 174) ressalta que "o processo de formação do ser humano reflete exatamente todas as possibilidades e todas as matizes dos seres que somos". O conceito da formação é algo complexo para o indivíduo, inicia-se em seu nascimento e reproduz comportamentos e normas que irão orientar a sua vida e expressar o que lhe é subjetivo (TEIXEIRA, 2004).

Em relação à formação de professores, Nóvoa (1992) pontua que ela deve fugir da proletarização e se voltar para a profissionalização do professor, em um processo em que os docentes reformulem a regulamentação da profissão, elevem os seus rendimentos e aumentem a autonomia sobre suas atividades. $\mathrm{O}$ autor assinala ainda que, para essa formação autônoma, são necessárias três dimensões essenciais: preparação acadêmica, preparação profissional e prática profissional (NÓVOA, 1992).

A idealização de um modelo teórico para orientar a formação do professor levou a uma concepção negativa da prática pedagógica e dos saberes docentes (NÓVOA, 1992). Atualmente, o enfoque investigativo para a renovação da formação de professores, no âmbito dos cursos de licenciatura, tem ocorrido por tendências contemporâneas e movimentos internacionais, direcionados à valorização da prática docente e dos saberes didático-metodológicos necessários a essa prática (NUNES, 2001; TEIXEIRA, 2004). Teixeira (2004) assevera que essas abordagens buscam fugir do racionalismo técnico e do ensino tradicional, centrado no professor detentor e transmissor do conhecimento, e segue ao encontro da racionalidade prática docente, que nas atuais pesquisas passa a ser entendida como eixo central do currículo da formação de professores, constituindo-se como o ponto de partida do currículo de formação.

As novas tendências estimulam o desenvolvimento de competências e saberes docentes (TARDIF, 2002; PIMENTA; GHEDIN, 2002) que advêm da reflexão sobre a prática do professor. Esses saberes, aliados à crítica, levam o professor a ressignificar sua atuação e a relativizar constantemente seus conhecimentos (SCHÖN, 2000; PIMENTA; GHEDIN, 2002; ZEICHNER, 2008). Nesse sentido, as novas tendências buscam a formação da identidade docente (MARCELO, 1998; PIMENTA, 2005; CARDOSO, 2010; FERREIRA, 2011), indissociável da identidade pessoal e profissional do professor (NÓVOA, 1992). Desse modo,

\footnotetext{
A formação deve estimular uma perspectiva crítico-reflexiva, que forneça aos professores os meios de um pensamento autônomo e que facilite as dinâmicas de autoformação participada. Estar em formação implica um investimento pessoal, um trabalho livre e criativo sobre os percursos e os projectos próprios, com vista à construção de uma identidade, que é também uma identidade profissional (NÓVOA, 1992, p. 14).
}

Na mesma perspectiva do ensino reflexivo, a construção dos saberes da docência por meio da reflexão escrita (diários) advêm do conhecimento extraído das experiências práticas, que na formação inicial são desenvolvidos durante os estágios, mas acompanham o profissional professor por toda a vida.

Para compreender o que são os saberes da docência, Pimenta (2005) assinala que eles são as habilidades que construirão a "identidade docente". A autora pontua que essa identidade é mutável e que é construída pelo significado com que cada professor, ator e autor de suas ações, concebe à atividade docente com base em seus valores pessoais. Essa construção, que se inicia na formação inicial, ocorre fundamentada nos 
saberes da docência que Pimenta (2005) divide em: "saberes da experiência", "saberes do conhecimento" e "saberes pedagógicos". A autora define que os primeiros vêm da experimentação na prática docente, construídos no cotidiano com a escola, nos planejamentos com os colegas e outros. O segundo, os "saberes do conhecimento", requer profundidade e ultrapassa as definições conceituais, mergulhando na compreensão do significado de ensinar determinado conteúdo. Os "saberes pedagógicos", segundo a autora, derivam dos dois anteriores e corroboram com a reflexão sobre o que se faz na prática (PIMENTA, 2005). Ela salienta, ainda, que é no desenvolvimento desse último saber que se faz tão necessária a relação entre teoria e prática, visto que "os saberes pedagógicos podem colaborar com a prática, sobretudo, se forem mobilizados com base nos problemas que a prática coloca, entendendo a dependência da teoria em relação à prática, pois esta lhe é interior" (PIMENTA, 2005, p. 27-28).

Essa identidade docente a que Pimenta (2005) se refere foi anteriormente explorada por Nóvoa (1992) ao abordar a complexidade em compreender o processo de formação docente por ser o professor uma pessoa, e uma parte importante dessa pessoa ser o professor (NIAS apud NÓvOA, 1992). Na ótica de Nóvoa (1992), é preciso buscar meios de realizar essa interação entre as dimensões pessoais e profissionais para que o professor se aproprie dessa formação e construa a sua identidade pessoal nessa função. Destaca-se que não se pode confundir os termos "formar" e "formar-se", pois a lógica das atividades educativas nem sempre coincide com as dinâmicas próprias da formação. De acordo com Nóvoa (1992, p. 13), "a formação não se constrói por acumulação (de cursos, de conhecimentos ou de técnicas), mas sim através de um trabalho de reflexividade crítica sobre as práticas e de (re)construção permanente de uma identidade pessoal".

Com o objetivo de fomentar a construção desse perfil docente pelos futuros professores, propostas como a elaboração do diário de aula antes, durante e depois das atuações em sala de aula, aliadas aos debates, proporcionam reflexões sobre a prática social docente, vindo a estimular, no período de formação, reflexões individuais com a escrita no diário (ZABALZA, 2004).

Historicamente, o diário de aula foi introduzido aos costumes da sociedade quando as moças, que eram proibidas de estudar, realizavam anotações periódicas em seus cadernos, lidos e corrigidos por suas mães ou por outras pessoas. Entretanto, as jovens escreviam seus anseios e angústias nos diários, e eles começaram a ser mal vistos pela igreja e pela sociedade, considerados um desvirtuamento dos bons costumes (GALIAZZI; LINDEMANN, 2003). Como se pode observar, a primeira função dos diários foi a de aprendizado da leitura e da escrita por meninas que não tinham acesso à escola. Nessa acepção,

O gênero diário se impôs em decorrência de fatos históricos e sociais que propagavam princípios sociais como a liberdade e a igualdade, mas que não se cumpriam na concretude da vida do indivíduo. O diário passou assim a ser usado como forma de construir sua própria história (GALIAZZI; LINDEMANN, 2003, p.137).

Com relação à classificação dos diários nos pressupostos da linguagem, Liberari (1999, p. 22), em sua tese sobre o uso do diário como ferramenta na reflexão crítica na formação de licenciandos de Letras, estabelece que eles são um gênero de linguagem porque "trabalhariam a objetividade da situação através da versão subjetiva que os sujeitos dão a ela e a subjetividade da situação através dos dados objetivos que o próprio documento pessoal proporciona".

Dessa forma, os diários podem ser compreendidos como um "gênero único", e algumas de suas características são definidas por Liberari (1999), tais como a ausência de destinatário empírico; o papel acentuado do 


\section{autêntica}

superdestinatário; o estabelecimento de contrato de confiança entre produtor e possível destinatário para a compreensão responsiva desse destinatário; a atribuição de franqueza, pelo locutor, ao discurso produzido; a presença de referentes afetivos e cognitivos; a construção de mundo discursivo temporalmente conjunto ao da situação de comunicação; a implicação do locutor, do tempo e do espaço da situação material de comunicação; a ausência de preocupação com procedimentos de textualidade como coesão e coerência; os objetivos múltiplos; e a criação de espaço para a constituição de subjetividades.

Em uma perspectiva didático-pedagógica, Galiazzi e Lindemann (2003, p. 139) afirmam que "as reflexões dos alunos a partir desse procedimento também apontam para o diário como instrumento mediador de reflexões e aprendizagens sobre ser professor." Porlán e Martín (1991) e Pietro (2003) argumentam que o diário do professor constitui um instrumento de análise do pensamento reflexivo de professores tanto em formação como em exercício. Ainda conforme Pietro (2003), o diário da prática pedagógica é um valioso instrumento que possibilita o abandono de condutas robotizadas e rotineiras nas classes, permitindo a reflexão e potencializando a capacidade dos docentes como geradores de conhecimento profissional.

Acredita-se, então, que o processo reflexivo na formação inicial de professores pode ser estimulado pelo uso do diário de aula (PORLÁN; MARTíN, 1991; LIBERARI, 1999; GALIAZZI; LINDEMANN, 2003; PIETRO, 2003; PANIZ, 2007; GIANOTTO, 2008a; 2008b; GIANOTTO; CARVALHO, 2015; BARREIROS; GIANOTTO, 2014; BARREIROS, 2015). A estratégia dos trabalhos aqui citados é a de utilizar os diários de aula para acompanhar as ações realizadas no período de formação do professor (inicial e continuada).

Zabalza (2004) atesta que o diário proporciona ao professor a autorreflexão de sua atuação, permitindo-lhe explorar sua prática e identificar possíveis erros e futuras melhorias, tornando-se autocrítico e investigador de seu desempenho, além de um pesquisador do ensino. Corrobora-se com os autores e, na busca de promover a reflexão na formação dos participantes do PIBID Biologia, defende-se que "produzir um diário não é simplesmente expressar o que se pensa, mas uma forma de perceber os próprios pensamentos, e mais que isto, uma forma de elaborar esses pensamentos" (MACHADO apud GALIAZZI; LINDEMANN, 2003, p. 137).

Algumas pesquisas direcionam-se a estudar o instrumento diário e investigam a promoção da reflexão dos participantes com sua utilização. Silva e Duarte (2001) utilizaram o diário para avaliar os resultados desse instrumento com estagiários de Biologia e Geologia em formação. O objetivo do trabalho foi avaliar o quanto o discurso do professor orientador do estágio supervisionado influência nas ações e nas reflexões dos estagiários. Segundo as autoras, o discurso dos estagiários, cuja orientação apresentava-se reflexiva, denotava participantes também reflexivos. Na visão das autoras, a potencialidade do diário ficou demonstrada nos trechos em que os estagiários realizaram agradecimentos pela intervenção, que havia propiciado grande reflexão sobre o trabalho por eles realizado.

Pedroso e Rosso (2004) trazem outro exemplo de análise desenvolvida com diário de aula, o qual foi preenchido durante o período de estágio supervisionado de estudantes de Matemática. Os autores afirmam que os resultados da análise demonstraram que o diário apresentou subsídios para mudanças significativas da disciplina e favoreceu de forma expressiva a construção de competências e de problematizações dos processos de ensino e aprendizagem, a autoanálise dos estagiários e fomentou o redimensionamento de suas ações futuras. Nessa linha de pesquisa, Gonçalves et al. (2008) investigou os dilemas e seus enfrentamentos no período de estágio da licenciatura de Química, observando três professores participantes que demonstraram seus dilemas e estabeleceram um contexto dialógico, evidenciando em suas atuações a exploração de conteúdos atitudinais no processo de ensino e aprendizagem. 


\section{autêntica}

Como se pode observar, o diário da prática pedagógica, quando incorporado às ações docentes, pode proporcionar ao professor uma autorreflexão, permitindo-Ihe explorar suas ações e identificar erros e formas de aprimoramento de sua prática. Outro autor que estimula o uso do diário de aula é Porlán (1987), para quem o diário do professor é uma ferramenta significativa no processo reflexivo, um instrumento básico para a investigação na aula, pois pode adaptar-se, por seu caráter pessoal, a todo tipo de circunstâncias.

Nesse sentido, o objetivo do presente artigo é investigar os limites e as possibilidades da utilização do diário de aula como instrumento pedagógico e reflexivo na formação inicial de acadêmicos do curso de Ciências Biológicas da UEM participantes do PIBID.

\section{CONTEXTO E CONSTITUIÇÃO DOS DADOS}

A investigação iniciou-se pela sensibilização e pelo debate do uso do diário e posteriormente pelo acompanhamento da sua elaboração durante o desenvolvimento do PIBID contemplado pelo Curso de Ciências Biológicas da UEM. Sobre esse contexto, o subprojeto da licenciatura em Biologia entrou em vigor em 2010, inicialmente com 20 participantes, que recebiam remuneração mensal, além do coordenador e responsável pelo projeto na instituição, que também recebe uma bolsa mensal, e seis professores da instituição universitária que participaram voluntariamente. Integraram ainda o subprojeto dois professores supervisores efetivos dos colégios contemplados, também bolsistas. Geralmente, a dinâmica do subprojeto reúne os participantes em duplas, os quais, em períodos determinados, desenvolvem uma sequência didática (SD) a ser aplicada nas escolas com o cronograma pré-estabelecido pelos participantes no início do ano letivo. Todas as ações do PIBID são sistematizadas na intenção de atingir o objetivo de

Promover a integração da formação inicial e continuada de professores na perspectiva de aperfeiçoar a prática pedagógica de Biologia, a partir da análise reflexiva acerca dos problemas didático-pedagógicos identificados e de ações que desenvolvam as capacidades cognitivas psicomotoras e afetivas dos estudantes do EM (UEM, 2009).

Em seu objetivo geral, o subprojeto se propõe a trabalhar os problemas didático-pedagógicos identificados pelos participantes através da análise reflexiva da prática pedagógica, o que corrobora com a investigação proposta por este trabalho. Assim, o PIBID Biologia da UEM, desde sua implementação, visa à formação de grupos reflexivos, com diferentes atores envolvidos com a docência, proporcionando por meio de uma constante pesquisa-ação a construção e a reflexão sobre a formação dos participantes, seja inicial ou continuada (UEM, 2013).

Nesse sentido, esta pesquisa foi realizada no período de novembro de 2013 a novembro de 2014 e apoiou-se na metodologia qualitativa (BOGDAN; BIKLEN, 1991). Os resultados foram obtidos a partir da investigação da prática reflexiva que utilizou, como instrumento de coleta de dados, os diários de aula produzidos por 19 licenciandos de Ciências Biológicas, que aceitaram participar da pesquisa (identificados por Acadêmicos Participantes, A1-A19). Assim, os sujeitos da pesquisa foram os participantes do PIBID Biologia da UEM, também chamados de pibidianos; e o objeto de estudo, suas narrativas nos diários de aula, elaboradas durante as atividades desenvolvidas nos encontros com os participantes e nas aulas por eles ministradas nas séries do ensino médio (EM) de duas escolas públicas da cidade de Maringá, Paraná. 


\section{autêntica}

\section{AÇÕES DESENVOLVIDAS NA PESQUISA}

As ações da pesquisa foram divididas em três etapas.

Na etapa inicial, foram planejados seis encontros, nos quais criaram-se situações de discussão entre os participantes, buscando valorizar a teoria como ferramenta de pensamento sobre a prática, selecionando-se uma metodologia (que implicou em uso de diversos recursos, bem como na busca de estratégias e procedimentos reflexivos) voltada para o despertar da atenção, da criatividade e do interesse dos alunos do EM, assim como para promover a reflexão dos participantes do PIBID. Para dar suporte às narrativas, as pesquisadoras proporcionaram orientação inicial aos participantes sobre como proceder na escrita dos diários, conforme a ficha de orientações na Fig. 1.

\section{FIGURA 1: ORIENTAÇÕES PARA AS NARRATIVAS NOS DIÁRIOS DE AULA}

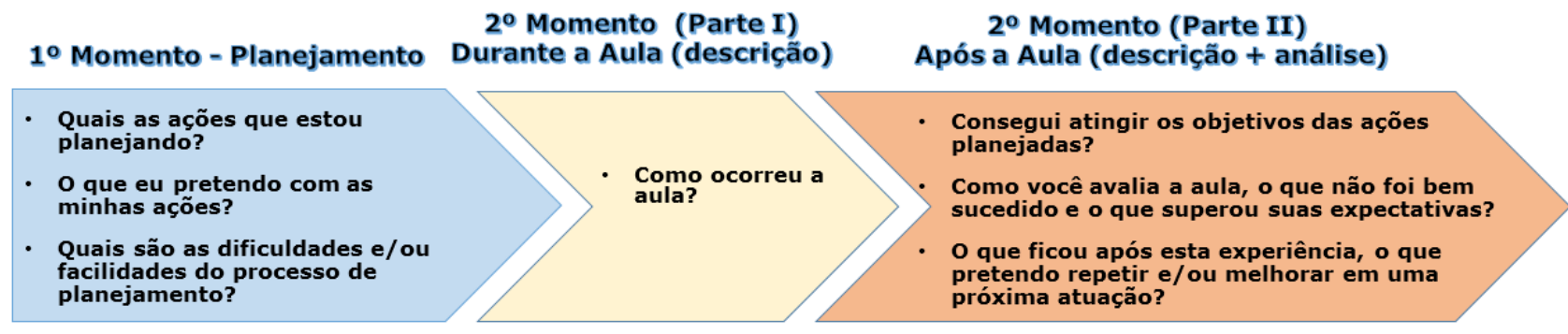

Fonte: elaboração própria.

Houve, portanto, por parte das pesquisadoras, preocupação com a atuação e o papel do futuro professor enquanto profissional responsável pela mediação no processo de ensino-aprendizagem. Segundo Libâneo (2000), o professor, ao assumir o ensino como mediação pedagógica, auxiliando os alunos no desenvolvimento de competências de pensar na medida em que coloca problemas, perguntas, dialoga e ouve, ensina a argumentar, abre espaço para que eles expressem desejos, pensamentos e sentimentos, trazendo sua realidade concreta para a sala de aula. Essa é uma postura imprescindível ao docente. Além dos estudos e das orientações iniciais, nessa primeira etapa foi realizado um levantamento das concepções dos participantes sobre o diário de aula e sua utilização na formação de professores.

Em uma segunda etapa realizou-se a análise dos diários de aula, descrita na seção análise e categorização dos diários. Apesar de a pesquisa ter sido realizada com 19 participantes, apenas 15 foram analisados, tendo em vista que 4 - A1, A4, A6 e A18 - não realizaram o preenchimento do diário.

Após 11 meses, retornou-se ao PIBID Biologia da UEM para uma terceira etapa, a fim de avaliar alguns aspectos acerca da experiência com o diário. Nem todos os participantes da primeira e segunda etapa estavam presentes no PIBID devido ao início de um novo ano letivo, sendo possível realizar entrevistas com seis dos participantes iniciais (A2, A5, A12, A13 e A14). Aos seis participantes remanescentes, questionou-se quais as contribuições e dificuldades em se utilizar o diário de aula.

\section{ANÁLISE E CATEGORIZAÇÃO DOS DIÁRIOS}


Nos diários foram encontrados: procedimentos, estratégias, metodologias e recursos didáticos utilizados pelos futuros professores durante o desenvolvimento das atividades do PIBID. A análise dessas narrativas presentes nos diários tomou como referência Bardin (1977), buscando-se responder às seguintes questões norteadoras: o diário de aula é um recurso pedagógico eficiente para ser utilizado na formação inicial? O uso do diário de aula incentiva a reflexão durante e após a ação e contribui para o futuro professor elaborar os saberes da docência (teóricos, experienciais e pedagógicos)? E, por fim, esse instrumento colabora para a construção da identidade profissional na formação inicial?

Para este estudo utilizou-se a técnica da análise categorial, realizando-se: I - levantamento das concepções prévias dos pibidianos acerca do diário; II - pré-análise dos dados (narrativas dos diários), os quais foram organizados, transcritos e lidos; III - exploração do material, para se chegar a uma representação do conteúdo dos documentos; IV - classificação dos elementos, impondo-lhes certa organização; e V - categorização dos dados, por meio de um texto, no qual estão presentes a inferência e a interpretação dos conteúdos.

Considerando que o uso do diário possibilita obter informações escritas sobre o que pensam os participantes do PIBID durante o processo de planificação ou quaisquer outras atividades por eles desempenhadas, o diário teve este intuito de elencar estas informações. A partir dessas ideias expressas, emergiram cinco categorias: observações e avaliações dos participantes; problemas e reflexões derivados da aplicação das ações pedagógicas; planejamento das atividades e pluralidade metodológica; o diário de aula como instrumento de reflexão. Essa última etapa foi elaborada a partir das avaliações realizadas na terceira.

Essas categorias engendram ou implicam aspectos objetivos (conteúdos ministrados; metodologias, técnicas e recursos didáticos; planejamentos; processos avaliativos e relação teoria-prática) e subjetivos (dificuldades enfrentadas em sala de aula; formação de habilidades docentes; reflexão no diário de aula; relacionamento professor-aluno e subjetividade na ação-reflexão) da formação docente.

\section{RESULTADOS E DISCUSSÃO}

Para identificar as interpretações dos participantes com relação ao diário de aula e validá-lo como instrumento de coleta de dados foi realizado um levantamento prévio a fim de elencar concepções sobre: o aluno conhecer ou não o diário; identificar um contato prévio do participante com o diário em outra oportunidade na graduação; e avaliar qual a recepção dos participantes a esse instrumento.

\section{CONCEPÇÕES PRÉVIAS À UTILIZAÇÃO DO DIÁRIO DE AULA}

Inicialmente, os participantes foram questionados sobre o que é e se já utilizaram o diário de aula e apresentaram visões discrepantes desse instrumento. Apesar de 12 participantes afirmarem conhecer o diário, com a análise das respostas constatou-se experiências diferentes, como descrito no quadro a seguir (Quadro 1). Identificou-se nas concepções prévias dos participantes que, apesar de alguma resistência, justificada pelo trabalho e pela falta de tempo em elaborar o diário, os participantes que o utilizaram notaram um desenvolvimento proporcionado pelo uso desse instrumento. Na mesma direção, aqueles que ainda não o utilizaram, em sua maioria, acreditam no potencial de organização da prática pedagógica pela utilização do diário. 


\section{autêntica}

QUADRO 1: CONCEPÇÕES PRÉVIAS ACERCA DO DIÁRIO DE AULA

\begin{tabular}{|c|c|c|}
\hline Concepções & Trechos dos diários & Participantes \\
\hline Não conhece & $\begin{array}{l}\text { "Não conheço, sendo assim nunca utilizei" (A2); "Não sei o que é." (A6); "Nunca utilizei, porque não } \\
\text { conhecia isso ainda" (A12); "Nunca utilizei diários de aula" (A18) }\end{array}$ & $\begin{array}{l}\mathrm{A} 2 ; \mathrm{A} 6 ; \mathrm{A} 10 \\
\text { A11;A12; } \\
\quad \text { A18. }\end{array}$ \\
\hline $\begin{array}{c}\text { Define o } \\
\text { instrumento }\end{array}$ & $\begin{array}{l}\text { "É um diário que o professor escreve sua prática pedagógica do dia a dia" (A10); "Não sei se minha } \\
\text { concepção de diário de aula é correta, mas acredito que seja um caderno no qual se registra tudo o } \\
\text { que foi realizado durante as aulas" (A11) }\end{array}$ & $\mathrm{A} 10 ; \mathrm{A} 11$ \\
\hline $\begin{array}{l}\text { Conhece, mas } \\
\text { nunca utilizou }\end{array}$ & $\begin{array}{l}\text { "Sim. Nunca fiz um diário de aula. Porque eu salvo tudo nas pastas do computador"(A4); "Sim, nunca } \\
\text { utilizei. Sou uma pessoa extremamente desorganizada, não consigo ser uma pessoa organizada"(A8) }\end{array}$ & $\mathrm{A} 4 ; \mathrm{A} 8$. \\
\hline Não utiliza & $\begin{array}{l}\text { "Não costumo usar. Talvez pelo comodismo ou pela falta de habito de não tomar nota de quase } \\
\text { nada"(A9) }\end{array}$ & A9; A14. \\
\hline $\begin{array}{l}\text { Acredita ser } \\
\text { trabalhoso }\end{array}$ & "É muito trabalhoso"(A14) & $\mathrm{A} 9 ; \mathrm{A} 14$ \\
\hline $\begin{array}{l}\text { Experiência } \\
\text { com o diário no } \\
\text { Estágio } \\
\text { Supervisionado } \\
\quad \text { /PIBID }\end{array}$ & $\begin{array}{l}\text { "Já utilizei durante o estágio e no projeto PIBID. Eu particularmente tenho dificuldades em criar um } \\
\text { hábito de escrita diária, às vezes deixo para fazer outro dia, e acabo esquecendo. Mas quando fiz } \\
\text { gostei muito da reflexão que ocorreu sobre minhas atitudes em sala de aula e até da própria dinâmica } \\
\text { da sala" (A10); "Sim. Já utilizei um 'diário' quando dei aula no estágio supervisionado. A experiência } \\
\text { foi boa, escrevia tudo que acontecia em sala de aula e colocava minha opiniãoe pensamentos" (A17) }\end{array}$ & $\begin{array}{l}\text { A3; A7; A10; } \\
\text { A15; A16; } \\
\text { A17. }\end{array}$ \\
\hline $\begin{array}{c}\text { Avalia o } \\
\text { instrumento }\end{array}$ & $\begin{array}{l}\text { "Talvez seja uma boa forma de registrar, para que não haja perda de atividades" (A11); "Nunca utilizei } \\
\text { diários de aula, mas seria uma experiência interessante, pois assim, poderia refletir quanto a minha } \\
\text { prática docente" (A18); "Sim, faço um resumo, em tópicos, do conteúdo passado para ter uma } \\
\text { continuidade e não faltar conteúdo para ser passado. É bom para organizar o conteúdo, saber o que já } \\
\text { foi passado em sala, etc." (A13); "Já utilizei um diário de aula e diversas vezes ainda uso para auxiliar } \\
\text { no meu entendimento da turma e também auxiliar no preparo das próximas aulas" (A19). }\end{array}$ & $\begin{array}{l}\text { A11; A13; } \\
\text { A18; } 19 .\end{array}$ \\
\hline $\begin{array}{l}\text { Critica a } \\
\text { utilização do } \\
\text { instrumento }\end{array}$ & $\begin{array}{l}\text { "Sei o que é um diário de aula, mas na minha modesta opinião é um veículo que não agrega nada } \\
\text { mais para a atividade docente. Nos dias atuais a carga de trabalho dado aos professores, bem como o } \\
\text { aumento de atividades e cobranças, isso seria mais um instrumento de sobrecarga as suas atividades. } \\
\text { Pois algo semelhante a esse diário o professor tem que fazer o diário de classe" (A1). }\end{array}$ & $\mathrm{A} 1$ \\
\hline
\end{tabular}

Fonte: elaboração própria.

Pautada nos objetivos no processo de investigação, além da intervenção e dos debates acerca dos temas, esta pesquisa se propôs a incentivar os participantes a confeccionar os diários de aula antes e depois de suas atuações em sala de aula.

A demanda de tempo é sempre questionada pelos licenciandos, já que o curso de Ciências Biológicas licenciatura é composto por um currículo extenso e complexo. Não se pode deixar de associar, também, que a dificuldade apontada por professores atuantes no sistema de ensino é a demanda do currículo versus tempo (CARVALHO, 2000; KRASILCHIK, 2004). O diário sob a abordagem reflexiva exige leituras e ponderações pessoais direcionadas, e sem esse devido tempo para a sua realização torna-se inviável desenvolver um trabalho que amplie a criticidade e a reflexão, tão importantes para a construção da identidade docente.

Será que os participantes, ainda em formação, ao demonstrarem preocupação com essa "falta de tempo", têm a dimensão real da carência de tempo que os docentes enfrentam? A esse respeito, Pimenta e Lucena (2004) afirmam que os estágios supervisionados, assim como o PIBID, são um recorte da realidade. Recorte esse que aproxima o acadêmico das funções do seu futuro trabalho, mas que está longe do ideal. A preocupação das autoras justifica-se porque esse recorte está longe de ser favorável ao processo de formação por meio da reflexão (PIMENTA; GHEDIN, 2002; ZEICHNER, 2008).

As análises dessas concepções prévias demonstram que os participantes, independentemente de terem contato com o diário de aula, apresentam duas visões: a primeira, favorável à escrita e à reflexão; e a segunda, com uma ligeira insatisfação por terem que utilizar o diário durante a participação, o que pode tornar 
sua escrita e reflexão algo negativo para esse participante. Contudo, ao longo do acompanhamento desses acadêmicos, mudanças nas suas concepções prévias poderão ser identificadas.

Em uma segunda etapa, foram analisadas as narrativas presentes nos diários de aula. Desse modo, a categorização e as análises, abordadas posteriormente, contemplam trechos dos diários de 15 participantes. A seguir, discorre-se sobre as 5 categorias analisadas.

\section{OBSERVAÇÕES E AVALIAÇÕES DOS PARTICIPANTES}

A reflexão acerca da estrutura escolar, do contexto da sala de aula e do comportamento dos alunos são detalhes importantes a serem captados e considerados nas atividades do docente. Como afirma Zabalza (2004), o simples fato de descrever as ações realizadas proporciona uma reflexão da própria prática e consequentemente dos detalhes relevantes para a futura prática docentes. Para melhor compreensão, essas observações e avaliações foram subdivididas em três subcategorias: participação dos alunos; autoavaliação e estrutura da escola.

\section{PARTICIPAÇÃO DOS ALUNOS}

Inicialmente, identificaram-se avaliações do comportamento dos alunos. Nesse sentido, os participantes demonstram um olhar crítico em relação à sala de aula: "Alguns alunos eram infrequentes, e isso dificultou o aprendizado de vários" (A9). Nesse trecho, o participante, além de notar que os alunos faltam, associou esse fato ao aprendizado deles, o que demonstra uma preocupação com a sequência do processo de ensino-aprendizado. Outra fala que demonstra como os participantes percebem a reação dos alunos, mesmo fora da sala de aula, em uma visita ao museu, é a de A3: "Maravilhados com os equipamentos e procedimentos, tiveram horas em que foi necessário a chamada de atenção dos alunos devido a essa euforia. Mas nada que pudesse ser desrespeitoso ou impedir a visita de ocorrer". Observa-se, nas avaliações das participações de seus alunos, que eles reconhecem como causa ou consequência os erros e/ou acertos em suas práticas pedagógicas.

Nessa mesma perspectiva, mas demonstrando o poder de descrição e análise dos diários, o participante A5 narra uma frustação: "Foram dados 30 minutos para a preparação das apresentações, mas as conversas paralelas atrapalhavam o rendimento da aula, o que me frustrou bastante"; e, no dia seguinte a essa frustação, A5 descreve: "Todos prestaram atenção nas apresentações e cada grupo se empenhou em compreender o texto e explicar para os outros alunos". Nas narrativas de A5, destaca-se que o acervo histórico (PORLÁN; MARTíN, 1991; ZABALZA, 2004) proporcionado pelo diário o fez identificar que as aulas são dinâmicas. Esse modo de avaliação negativa, seguida de outra positiva das atuações nos diários analisados é bastante comum, o que demonstra o quanto a prática experienciada é necessária à formação desses profissionais (PIMENTA, 2005). Nota-se também em outras narrativas que, em meio às expectativas dos participantes quanto à reação dos alunos à sua prática, ocorrem surpresas: "Achei que os alunos fossem ficar dispersos, por não gostarem de mim e da minha dupla. Porém, os alunos se mostraram bastante interessados e ouviram atentamente as explicações" (A8).

Esse aperfeiçoamento da prática docente identificado por meio de erros, frustações, acertos e surpresas é um indício de reflexão no contexto do PIBID. Destaca-se que a reflexão cotidiana é inegável ao ser humano e, como ressaltado por Zeichner (2008), que tais falas analisadas podem tratar-se de reflexões pouco aprofundadas - "ilusões da reflexão". Porém, para que esses licenciandos deixem a ilusão e tornem-se autocríticos com relação a sua futura prática docente, faz-se necessário iniciar esse processo de escrita, análise e diagnóstico durante a formação, que os trechos analisados sugerem ocorrer. 


\section{autêntica}

\section{AUTOAVALIAÇÃO}

A grande maioria avalia de forma positiva sua atuação: "A aula ocorreu superbem" (A14); "Atingi meus objetivos" (A8). Além disso, justificam essa avaliação positiva expondo argumentos: "O número de participantes aumentou para 20 e manteve-se com essa média. Esse fato me deixou muito feliz e mostrou que os alunos não estavam frequentando a sequência (didática) apenas para ganharem um ponto extra na disciplina de Biologia" (A16). As avaliações negativas, em menor frequência, são observadas também: "Buscamos trabaIhar o assunto de uma maneira dinâmica [...], porém eles pareceram desanimados" (A9).

Em outra perspectiva de autoavaliação, os participantes analisam ser interessante: I - conhecer a turma previamente para realizar os planejamentos: "Quando conhecemos a turma é mais fácil identificar o que daria certo e o que não funcionaria para aqueles alunos" (A7); II - comparar as atuações e o desenvolvimento da aula em turmas diferentes: "A primeira turma foi mais parada, sem muita participação, acredito que o motivo foi o 'sono' da primeira aula" (A2). A comparação fica evidente mesmo quando realizavam ações pedagógicas com planejamento idênticos, como no trecho seguinte: "No dia seguinte aplicamos uma oficina com o mesmo tema no colégio $X$. Os alunos se mostraram bem resistentes a nossa proposta, nos obrigando a desprender um grande tempo para instigar a participação dos mesmos" (A2).

A fala do participante A2 chama atenção, visto que, além de perceber que as turmas são diferentes, ele percebeu também que a aula é um ambiente enérgico. Desse modo, planejar e improvisar algo durante a prática pedagógica é algo complexo, porém necessário. Explorar esse conhecimento inesperado, descrito por Schön (2000) como conhecimento "tácito", é um exercício crucial na formação de professores e valoriza a experiência prática durante a construção da identidade docente e de sua profissionalização (NÓVOA, 1992; GARCÍA, 1999; PIMENTA, 2005). Essa reflexão sobre a ação é imprescindível, a fim de moldar e modificar ações que talham o pensamento e a reflexão dos licenciandos. Refletir sobre a prática docente promove ações pedagógicas que podem incentivar os alunos a também desenvolverem a reflexão para construir seu próprio conhecimento.

Assim, ter uma formação que dê subsídios para essa reflexão faz-se necessário. Nesse sentido, o PIBID vislumbra essa formação, como ressaltado no Edital Nacional MEC/CAPES/FNDE, item " $h$ ": "valorização do espaço da escola pública como campo de experiência para a construção do conhecimento na formação de professores para a educação básica" (BRASIL, 2007). Da mesma maneira, é o intuito do PIBID Biologia da UEM, sendo ele, contudo, mais focado na análise reflexiva, como se identifica no objetivo citado anteriormente.

\section{ESTRUTURA ESCOLAR}

Um terceiro aspecto abordado nos diários é a estrutura da escola. Muitas vezes precária e burocrática, essa variável tem reflexo direto na dinâmica da aula e no comportamento dos alunos, como evidenciado na fala de A14: "Tivemos que usar as tomadas da lateral na parede e visualizar através da lupa, isso fez que formasse uma fila enorme para ver os animais e alguns alunos conversavam muito alto na espera, o que fez com que chamássemos atenção deles". A avaliação da estrutura ou da falta dela nas escolas é uma ponte para os problemas enfrentados, e as ponderações sobre a experiência prática, assuntos da categoria seguinte.

\section{PROBLEMAS E REFLEXÕES DERIVADOS DA PRÁTICA PEDAGÓGICA}

Esta categoria aborda os dilemas enfrentados durante a prática no PIBID, analisando-se as narrativas dos diários. A análise em questão foi subdividida em três subcategorias, com base nos saberes docentes definidos por Pimenta (2005): saberes da experiência, específicos e pedagógicos. 


\section{SABERES ESPECÍFICOS}

O primeiro aspecto em destaque é a dificuldade pedagógica de realizar a transposição didática do conhecimento científico, uma vez que o participante aprende na graduação de um modo, e em sala de aula precisa trabalhar de forma menos complexa, em uma linguagem acessível ao aluno. Essa dificuldade é observada na fala de A9: "SD, de Embriologia. Aula: Gástrula à Neurula - A aula mais difícil de ser aplicada no meu ponto de vista. Foi complicada pelo ponto de ter de fazer entender o fator da tridimensionalidade do desenvolvimento embrionário" (A9). Para A12, a temática complexa é outra: "O tema da nossa oficina era Evolução, mas tínhamos que abordar os aspectos da história e filosofia da evolução, o que não é muito simples" (A12). Já o participante A14 sofre com a botânica: "Minha dificuldade hoje foi a incerteza do amanhã. Tive que montar duas aulas e estudar muito as famílias de algumas plantas para não passar vergonha amanhã" (A14). O participante A19 descreve as dificuldades dos alunos em compreender conceitos microscópicos: "Estudar Química com essa turma foi bastante desafiador. Para jovens que não ouviram falar de células, bactérias e outros seres microscópicos, é complexo explicar a existência de átomos, que são muito menores" (A19).

O participante A15 demonstra uma dificuldade semelhante não somente em transpor, mas também em encontrar estratégias didáticas: " $1^{\circ}$ ) Dificuldades: encontrar um tema adequado para relacionar com o conteúdo e decidir a metodologia mais eficiente para usar em sala, referente àquele tema. Dificuldade: na maioria das vezes é entender o assunto para explicar aos alunos" (A15). Nesse caso, o pibidiano demonstra dificuldades com o conhecimento específico e com o pedagógico.

Em uma continuidade da narrativa, o participante A15 tece uma avaliação positiva e, apesar de contraditório, deixa transparecer que não agradou: "Eu queria uma aula mais dinâmica, em que todos participassem e aplicassem os métodos estudados. No entanto, alguns alunos não participaram da forma como eu gostaria e nem sei se eu consegui explicar a prática da forma correta, mas acho que foi legal" (A15).

\section{SABERES DA EXPERIÊNCIA}

Há uma tendência dos participantes a refletirem sobre a experiência positivamente, mesmo quando nas entrelinhas demonstram não ter sido tão positiva. Esse fato aponta para a importância de experienciar erros e acertos da futura profissão antes de estar atuando realmente. Com relação às dúvidas sobre como realizar os ritos pedagógicos, elas são próprias dessa fase de construção do profissional docente, como eles mesmo reconhecem: "Minha maior dificuldade durante o planejamento é relacionar a minha prática em sala de aula com os objetivos propostos no papel. Tenho problemas também na fase da aplicação do conhecimento, em que fico muito preso apenas em exercícios" (A10). Assim como A10, os participantes têm preocupações e expectativas do rendimento: "É muito frustrante quando nada sai como o esperado, ao final da oficina senti que os objetivos não foram alcançados e que os alunos, apesar de terem gostado, não aprenderam muito" (A12).

Sobre esses aspectos, Pimenta (2005) descreve que, para desenvolver as demandas presentes na atividade do professor, os licenciandos precisam ampliar o que ela chama de saberes da docência. Segundo a autora, esses saberes iniciam-se pelos "saberes da experiência", aqueles construídos no cotidiano com a escola, o planejamento, os colegas, etc. Outros saberes são os "do conhecimento", que para a autora vão além da apropriação de conceitos e mergulham na essência e compreensão do significado de ensinar dado conteúdo. Por último, os "saberes pedagógicos" que, conforme a autora, emanam dos dois anteriores e corroboram com a reflexão sobre o que se faz na prática, destacando as habilidades que devem ser desenvolvidas durante a formação: 


\section{autêntica}

Frequentando os cursos de formação, os futuros professores poderão adquirir saberes sobre a educação e sobre a pedagogia, mas não estarão aptos a falar de saberes pedagógicos. A especificidade da formação pedagógica, tanto a inicial como a contínua, não é refletir sobre o que se vai fazer, nem sobre o que se deve fazer, mas sobre o que se faz (PIMENTA, 2005, p. 26).

Dessa maneira, evidencia-se que o diário de aula proporciona a reflexão sobre o que se faz, mesmo que em um recorte da realidade, e assim colabora para o caminho da formação inicial desses participantes e para o amadurecimento dos saberes pedagógicos, corroborando a opinião de Pimenta (2005).

Ainda nas narrativas dos participantes, verificamos que boas ideias esbarram em problemas como estrutura da escola ou falta de recursos financeiros para se colocar em prática, como evidenciados nos trechos de A12, que tenta vencer as dificuldades do conteúdo de história da evolução com um jogo didático: "Durante as semanas seguintes, [...] pensei em mandar imprimir um mapa gigante com os lugares que Darwin passou em sua viagem pela América. Levei minha ideia para (nome da colega) e ela gostou, porém, o inconveniente é que [...] iríamos gastar demais" (A12). Do mesmo modo, A14 se queixa das condições do laboratório: "O laboratório ficou pequeno para o número de alunos. [...] A TV Pendrive do laboratório não ligava e nem os microscópios, as tomadas da mesa do laboratório não estavam funcionando" (A14).

O mesmo ocorreu com os experimentos de A2 e A3: "Acredito que a primeira prática deu errado ou não chegou no resultado esperado por utilizarmos um álcool que estava no colégio" (A2); "Fiquei decepcionado com o fato de que os microscópios do Kit da Capes não conseguiram focar as células sanguíneas" (A3). Do mesmo modo, durante a visita ao hemocentro planejada pelo participante A3: "Só um desabafo: pensa numa dor de cabeça [...]. Está uma burocracia danada por causa do transporte" (A3). A falta de estrutura e o excesso de burocracia no sistema de ensino brasileiro (LIBÂNEO; OLIVEIRA; TOSCHI, 2003) é amplamente conhecida pelos professores atuantes e, diante das narrativas dos pibidianos, percebe-se que ela cerceia a criatividade do profissional docente antes mesmo de ela florescer na prática. Essa criatividade exige transpor essas barreiras da estrutura e do tempo de aula definido pelo sistema de ensino. Isso é desafiador aos licenciandos participantes do PIBID, como destaca-se no trecho de A7:

Para mim, existem duas maiores dificuldades para planejar uma aula. Primeiro, ter ideias criativas para abordar o conteúdo e (agora é mais complicado ainda) procedimentos que sejam viáveis no tempo que temos disponível [...] Acredito que procedimentos metodológicos que se encaixem no cronograma constituem uma grande dificuldade (A7).

A pluralidade nas concepções dos participantes fica evidente quando a dificuldade de A7 é uma facilidade para A10: "Tenho facilidade na busca de temas geradores que possam servir de base para as minhas aulas, também sou muito criativo na criação de situações-problema e de formas diferenciadas de se apresentar determinado conteúdo" (A10).

\section{SABERES PEDAGÓGICOS}

Os sujeitos envolvidos no processo de ensino-aprendizagem presentes na sala de aula tornam esse ambiente multifatorial, e desse modo a criatividade ou a capacidade de criar estratégias didáticas que prezem por um ensino dinâmico e que faz pensar não abstêm os professores de sofrer imprevistos e de ter que 
tomar decisões rápidas, como evidenciado na fala de A3: “Mesmo com o planejamento prévio e alterações para dinamizar ainda mais a sequência didática, imprevistos parecem que me perseguem de algum modo".

Outro apontamento com relação à problemática da prática extraída das narrativas é o fator "tempo". Já evidenciada na fala anterior do participante A7, essa problemática está presente em diversos relatos: "Não conseguimos fazer tudo que planejamos, o tempo foi curto. Só observamos as duas amostras de água e algumas espécies encontradas nela" (A14); "O número de aulas foi muito pouco para a quantidade de conteúdo, as aulas foram cansativas e os alunos reclamam da quantidade de conteúdo" (A12).

O tempo diz respeito à habilidade de planejar, distribuir e controlar as ações pedagógicas durante o período exato da hora aula, que não é extenso (50 minutos), e por isso exige uma organização não apenas pedagógica, mas também mental, na qual os licenciandos ainda não dominam o saber fazer, que apenas se desenvolve com a experiência. Sobre esse desenvolvimento do professor, Nóvoa (1992) explana que a permanente construção e reconstrução ocorrerão por toda vida profissional do docente. No mesmo sentido, Pimenta (2005) ressalta ser crucial que isso ocorra durante a formação, visto que sem a reflexão sobre o que se faz, ou seja, sem os saberes da experiência, o aprendizado é acrítico e desconexo do contexto.

Com menor citação nos diários, a indisciplina dos alunos emerge nas narrativas também como um problema enfrentado pelos pibidianos, como na fala de A8, em um caso de agressão verbal: "Logo no começo, eu dei uma bronca nos alunos, e uma aluna me chamou de ${ }^{* * *}$ (xingamento). Fiquei desorientada e sem saber o que fazer" (A8).

Como evidenciado na fala do pibidiano anteriormente, a indisciplina faz parte do dia a dia da escola, e esses dilemas podem ser estopins para a reflexão durante a prática e sobre ela (SCHÖN, 2000). Segundo Garcia (1999), a indisciplina é um dilema do professor em conjunto com a instituição escolar. O conceito do que é a indisciplina na escola é algo complexo que deve ser debatido durante a formação, para compreensão de sua amplitude. Esse autor define a indisciplina em três dimensões: a conduta do aluno; o processo de socialização e relacionamento com a instituição escolar e seus membros; e o aspecto do desenvolvimento cognitivo do aluno. Para o autor:

[...] define-se indisciplina como a incongruência entre os critérios e expectativas assumidos pela escola (que supostamente refletem o pensamento da comunidade escolar) em termos de comportamento, atitudes, socialização, relacionamentos e desenvolvimento cognitivo, e aquilo que demonstram os estudantes (GARCIA, 1999, p.102).

Sobre as narrativas analisadas nessa categoria sobre a práxis dos participantes, revelou-se licenciandos críticos e preocupados com o processo de ensino-aprendizagem: "Enfim, senti que os alunos se sentiram em uma aula de pré-vestibular, [...] mas o objetivo da aula não era esse" (A3). Essa preocupação diz respeito ao objetivo da aula, no qual entende ser algo mais significativo que uma aula de memorização de conceitos, mecânica e reproducionista, para exames de seleção.

Além disso, demonstram desenvolver ou estarem desenvolvendo a resiliência para lidar com os problemas da prática que já são enfrentados pelos professores: "Preciso aprender a lidar com essas situações, pois parece que sempre terá que ser feito além do planejamento um plano $B$, por que só assim para não se frustrar...e olha lá" (A3). Esse mesmo participante em seguida relata que apesar dos problemas obteve êxito: "Resolvido o problema do transporte (a professora titular conseguiu um ônibus depois de muitas tentativas frustradas), 


\section{autêntica}

os alunos foram ao hemocentro" (A3). Em consonância, A12 expõe sua frustação e faz uma reflexão importante para sua futura profissão: "Em uma aula prática que ministrei para o primeiro ano sobre fermentação, aconteceu um erro (que não consegui descobrir qual era). Fiquei um pouco frustrada, mas estamos sempre sujeitos a erros durante as práticas" (A12).

Como se denota, a experiência vivenciada no PIBID ampliou a visão dos licenciandos acerca de diversos problemas enfrentados durante as aulas, tais como dificuldades em interpretar conteúdos que precisam ensinar (saberes específicos), imprevistos durante sua execução (saberes da experiência) e como realizar e melhorar a dinâmica de planejamento pedagógico das aulas (saberes pedagógicos).Ao registrarem essas narrativas, os participantes têm a possibilidade de refletir e buscar soluções para essas percepções, como esquematizado na Fig. 2:

FIGURA 2: ESQUEMA DA CATEGORIA PROBLEMAS E REFLEXÕES DAS AÇÕES PEDAGÓGICAS

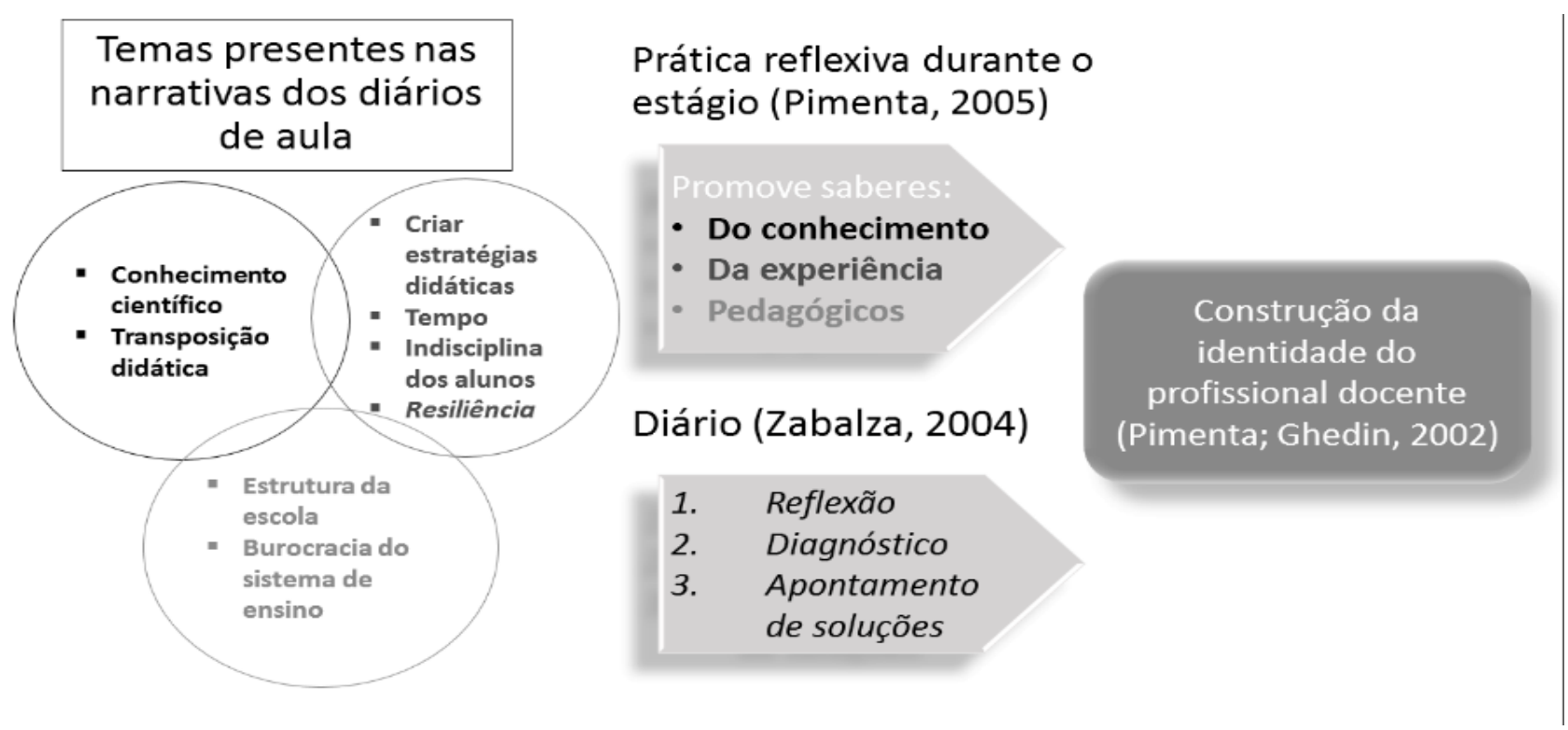

Fonte: Elaboração própria.

Os temas categorizados em relação aos problemas e às reflexões da prática dos participantes estão interligados em círculos, tendo em vista que apresentam correlações mútuas com os três saberes docentes. Assim, os diferentes círculos que representam a necessidade ou o desenvolvimento de um determinado saber docente, representado pela cor da fonte (preto, cinza escuro e cinza claro), apresentam temas como: o conhecimento e o aprofundamento específico da disciplina de Biologia, os diferentes modos de lidar com a situação prática durante a experiência e a criação e o pensamento pedagógico sobre esses enfrentamentos da prática. Assim, inicialmente, em uma perspectiva de análise, os temas estão alocados em um saber docente específico. Porém, para a formação do futuro professor, ocorre uma visão conjunta dos três saberes, pois as questões em sala de aula são multifatoriais.

Demonstra-se, desse modo, que a ação de formar-se é ativa, ou seja, exige a construção da identidade profissional docente pelo sujeito (GARCÍA, 1999), e ocorre quando por ocasião das reflexões (conscientes) sobre o fazer pedagógico em sala de aula. Ela também requer o desenvolvimento do saber fazer a partir da racionalidade prática, sob perspectiva dos saberes docentes, não como níveis a serem alcançados, mas sim saberes mutuamente construídos e reconstruídos na formação inicial e continuada, por meio de teoria, prática e reflexão crítica dessa prática (NÓVOA, 1992; SCHÖN, 2000; PIMENTA, 2005). 
Nessa interpretação do desenvolvimento de saberes docentes por meio do pensamento crítico da experiência, o diário, com seu poder de diagnóstico e reflexão, realiza um acervo histórico dessa prática do participante, permitindo o apontamento de soluções e o desenvolvimento da resiliência de seus escritores, e por isso na Fig. 2 ambos se direcionam como caminhos para a construção de um perfil docente subjetivo.

Sobre esse aspecto, Pimenta (2005) ressalta a importância de constituir sistematicamente o registro da experiência para a elaboração de teorias próprias ao professor.

Nas práticas docentes estão contidos elementos extremamente importantes, como a problematização, a intencionalidade para encontrar soluções, a experimentação metodológica, o enfrentamento de situações de ensino complexas, as tentativas mais radicais, mais ricas e mais sugestivas de uma didática inovadora, que ainda não está configurada teoricamente (PIMENTA, 2005, p. 27).

Essa visão da autora demonstra a capacidade do docente de construir a partir das suas práxis e metodologias inovadoras, o que corrobora com a utilização do diário como instrumento de acervo dessas metodologias e reflexão sobre elas.

Em prosseguimento às análises dos diários, outros apontamentos foram levantados, tais como as preocupações com o planejamento e as estratégias metodológicas (recursos e modalidades didáticas) utilizadas, aspectos discutidos na próxima categoria.

\section{PLANEJAMENTO DAS ATIVIDADES E PLURALIDADE DE METODOLÓGICA}

Em relação à realização do planejamento das atividades, 7 pibidianos relatam nas narrativas dos diários os apontamentos que foram organizados no quadro abaixo:

QUADRO 2: RELATOS SOBRE O PLANEJAMENTO

\begin{tabular}{|c|c|}
\hline $\begin{array}{l}\text { Relatos sobre o } \\
\text { planejamento } \\
\text { das atividades }\end{array}$ & Trechos dos diários \\
\hline Dificuldades & "É difícil!" (A3, A7, A10 e A15) \\
\hline Paixão/Amor & $\begin{array}{c}\text { "A arte de planejar é minuciosa, requer tempo, paciência, criatividade e paixão. Ou você faz com amor ou é } \\
\text { melhor nem ousar!" "[...] os alunos merecem uma aula de qualidade, na qual eles percebam seu papel naquele } \\
\text { momento e que entendam perfeitamente os objetivos" (A3). }\end{array}$ \\
\hline Facilidades & $\begin{array}{l}\text { [...] "remanejar um planejamento, remanejar é bem fácil!"(A3); "Como planejei e apliquei a sequência didática } \\
\text { antes de entrar na sala de aula e apenas fiz algumas modificações depois, não tive dificuldades" (A7). }\end{array}$ \\
\hline $\begin{array}{l}\text { Direcionamento } \\
\text { para as atuações }\end{array}$ & $\begin{array}{c}\text { "Primeiro penso como vou abordar o conteúdo com os alunos, se vou utilizar algum contexto histórico, } \\
\text { conhecimento de senso comum ou se vou começar com uma prática. Depois penso na metodologia que vou } \\
\text { utilizare como vou inserir o conteúdo dentro dela" (A11) }\end{array}$ \\
\hline $\begin{array}{l}\text { Avaliação da } \\
\text { formação }\end{array}$ & $\begin{array}{l}\text { "Havíamos planejado prática de protozoários e fungos, mas tivemos que interromper a sequência, pois a } \\
\text { orientadora corrigiu o planoe pediu para refazermos porque não estava bom" (A12) }\end{array}$ \\
\hline $\begin{array}{l}\text { Reflexões na ação } \\
\text { para os próximos } \\
\text { planejamentos }\end{array}$ & $\begin{array}{c}\text { "Durante a aula ocorrida, fiquei ali pensando na próxima aula, e como eu já sabia o conteúdo dela, bolei no } \\
\text { pensamento uma prática microscópica, na qual os alunos irão construir o relatório de pratica sobre as células } \\
\text { sanguíneas" (A3) }\end{array}$ \\
\hline $\begin{array}{l}\text { Ocorreu como } \\
\text { planejado }\end{array}$ & "Então tudo ficou certo para a aula a seguir como previamente planejado" (A3) \\
\hline $\begin{array}{l}\text { Fugiu do } \\
\text { planejamento }\end{array}$ & $\begin{array}{l}\text { "É muito frustrante quando nada sai como o esperado, ao final da oficina senti que os objetivos não foram } \\
\text { alcançados e os alunos apesar de terem gostado, não aprenderam muito" (A12) }\end{array}$ \\
\hline Perfeição & $\begin{array}{l}\text { "É claro que nem toda aula planejada é perfeita, mesmo porque cada um pensa de um jeito, tem uma } \\
\text { fundamentação a seguir, ou seja, não existe mesmo uma receita de como preparar uma aula" (A3) }\end{array}$ \\
\hline
\end{tabular}




\section{autêntica}

No quadro evidencia-se que quatro pibidianos (A3, A7, A10 e A15) apresentam dificuldades ao planejar. Eles apontam como dificuldade possuir domínio do conteúdo, ter ideias criativas, criar estratégias didáticas no tempo determinado e colocá-las no papel. Essas dificuldades remetem à discussão da categoria anterior com o desenvolvimento dos saberes docentes. Tendo ou não dificuldades, o planejamento é a base para a atuação dos participantes, pois é ele que estrutura a aula como na fala de A11. Contudo, os participantes preocupam-se em concretizá-lo do modo previamente idealizado, e por esse motivo nos diários encontra-se essa preocupação quando o planejamento concretiza-se fielmente e/ou quando foge. Refletindo sobre essa busca pela realização perfeita do planejamento, A3 afirma ser impossível esse rigor. Essa linha de raciocínio nos diários justifica o porquê de algum modo os participantes serem avaliados no contexto do PIBID (formação inicial).

Observa-se também que o participante A3 demonstra a preocupação com o processo ensino-aprendizagem do aluno, porém, ao abordar a qualidade do ensino, utiliza o termo paixão/amor, dando a ideia de que o ensino é vocacionado, e que o professor precisa essencialmente desses sentimentos para ministrar aulas. Sobre essa concepção de vocação e/ou amor à profissão, faz-se necessário destacar que, apesar de ser essencial o gostar de ser professor, é preciso muitos outros aspectos formativos e de desenvolvimento para tornar-se um docente. Nesse sentido, Alves (2006, p. 12) esclarece que

[...] pode ser um fator presente no exercício do magistério, especialmente na educação infantil. Porém, se temos que reconhecer a importância dessa chamada vocação, torna-se fundamental desmistificar a sua naturalização: vocação não é um dom inato, mas uma capacidade de realizar bem o trabalho, de superar as dificuldades e lutar pela qualidade da educação. Então, é uma característica profissional aprendida e desenvolvida com muito esforço e estudo.

Ainda sobre os relatos que compõem o Quadro 2, o planejamento não é mencionado apenas como dificuldade, mas há também apontamentos sobre a importância de planejar e replanejar. A prática não somente inspira, como também passa segurança, no que diz respeito ao conhecimento específico a ser ensinado e evidenciado na fala de A7 sobre a aplicação de um planejamento pela segunda vez.

Os participantes expõem também suas facilidades em planejar, tais como conhecer a turma e ter domínio do conteúdo já evidenciado na primeira categoria. Além dos aspectos relacionados ao ato de planejar as aulas, os pibidianos discorrem sobre as estratégias metodológicas utilizadas. Para demonstrar a pluralidade de recursos e modalidades didáticas citadas, elaborou-se a figura a seguir (Figura 3). Ela apresenta uma lista com os recursos e as modalidades didáticas, obedecendo à ordem de diários analisados de $\mathrm{A} 1$ a A19, exceto os 4 participantes que não o preencheram. Além dessa ordem, podemos observar as estratégias didáticas citadas 5 ou mais vezes (em branco), representando as com maior ocorrência nos diários analisados. A frequência em si não demonstra significância, e o que nos chama a atenção na figura anterior é a demonstração de uma pluralidade metodológica dos participantes descrita nos diários, tanto no que se refere aos recursos didáticos utilizados, quanto às modalidades de ensino. 


\section{autêntica}

FIGURA 3: PLURALIDADE METODOLÓGICA PRESENTE NOS DIÁRIOS

\begin{tabular}{|c|}
\hline $\begin{array}{c}\text { Recursos didáticos } * * \\
\begin{array}{c}\text { Atividades e exercícios (relatórios, } \\
\text { perguntas, etc.) }\end{array}\end{array}$ \\
\hline $\begin{array}{l}\text { Textos (científicos, reportagens, } \\
\text { receita culinária, etc.) }\end{array}$ \\
\hline $\begin{array}{c}\text { Jogos didáticos (físicos, virtuais, } \\
\text { etc.) }\end{array}$ \\
\hline $\begin{array}{l}\text { Recursos Audiovisuais (Vídeos, } \\
\text { Slides, Fotos, Filmes, Músicas, etc.) }\end{array}$ \\
\hline Data show \\
\hline Computador \\
\hline Microscópio \\
\hline Quadro e giz \\
\hline Massa de modelar \\
\hline TV pen drive \\
\hline $\begin{array}{l}\text { Materiais didáticos (Modelos, } \\
\text { cartazes espécimes biológicos, etc.) }\end{array}$ \\
\hline
\end{tabular}

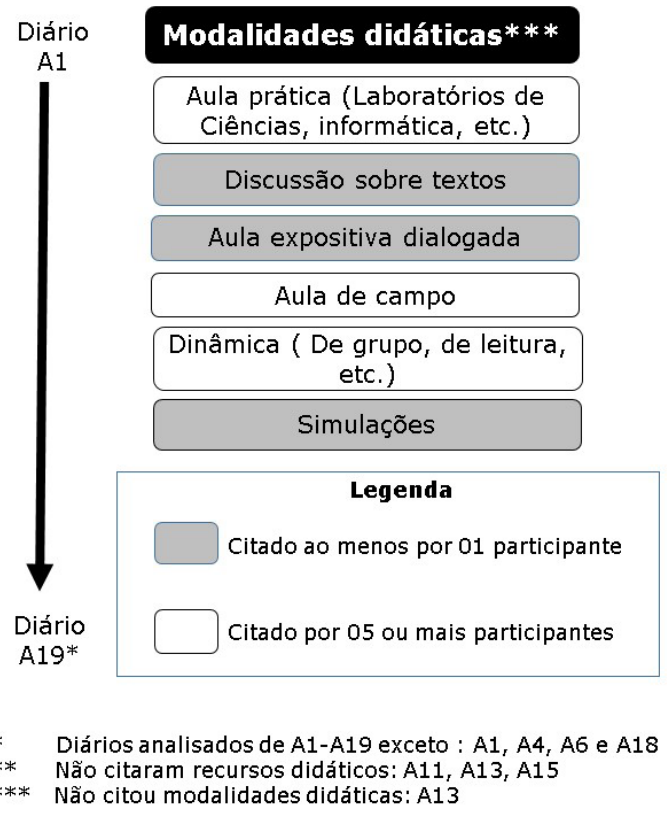

Fonte: elaboração própria.

Por se tratar do contexto do PIBID que investe, segundo seus princípios originais, no desenvolvimento de ações pedagógicas efetivas e inovadoras, como se evidencia no item "g)" do Edital Nacional de Seleção (BRASIL, 2007): "fomentar experiências metodológicas e práticas docentes de caráter inovador, que utilizem recursos de tecnologia da informação e da comunicação, e que se orientem para a superação de problemas identificados no processo ensino-aprendizagem". Com base nos objetivos originários do PIBID e do subprojeto Biologia da UEM, é possível verificar uma pluralidade metodológica que, conforme Amaral (2006, p. 3), promove um alcance que amplia o horizonte do aluno:

Quanto aos fatores didáticos determinantes das diferenças de abordagem de um conteúdo, teremos uma grande variedade de situações possíveis. Haverá casos em que a responsável pela diversidade de abordagem será a mudança da técnica de ensino. Ao se trocar uma por outra, deixam-se de lado alguns ângulos da exploração do conteúdo e abrem-se outros mais propícios [...] O mesmo acontece quando o que se troca é o recurso didático.

Em uma perspectiva interdisciplinar, Laburú, Arruda e Nardi (2003) embasam a sua proposta de pluralidade metodológica, constatando que não se pode utilizar uma atividade singular, ou seja, um único método em sala de aula que seja bem-sucedido para todos os aprendizes. Os prejuízos, segundo o autor, em se realizar essa singularidade metodológica é o reforço de apenas um modo de aprender, podando-se potenciais habilidades criativas e/ou sendo menos eficaz. Nesse sentido, o autor ressalta a complexidade da aprendizagem, que é um fenômeno que depende de fatores biológicos, psicológicos e sociais.

A prática pluralista proporciona, segundo esses autores (LABURÚ; ARRUDA; NARDI, 2003; AMARAL, 2006), a mudança e/ou inovação, além de dinamizar as propostas em salas de aula. Desse modo, Laburú, Arruda e Nardi $(2003$, p. 258) falam sobre como essa pluralidade pode favorecer o trabalho do professor e/ou licenciando: "[...] quanto mais variado e rico for o meio intelectual, metodológico ou didático fornecido pelo professor, maiores condições ele terá de desenvolver uma aprendizagem significativa da maioria de seus alunos". 


\section{autêntica}

Sob esses aspectos, o PIBID Biologia da UEM aponta fortes indícios para uma formação prática que reflete sobre a utilização de diferentes recursos e modalidades didáticas nas atividades desenvolvidas por seus participantes. Assim, na categoria seguinte será analisado o contexto do PIBID nas falas dos diários.

\section{O DIÁRIO DE AULA COMO INSTRUMENTO DE REFLEXÃO}

No contexto das narrativas, os participantes descreveram suas críticas ao diário e sua utilização:

Na minha opinião, com base na minha experiência com o diário do professor, o diário não é uma ferramenta eficaz para a reflexão do professor quando a pessoa não tem costume de escrever seus pensamentos [...] Resumindo, acredito sim que o diário auxilie o professor em sua prática, porém não são para todos os professores que isso se aplica (A12).

Enquanto alguns participantes demonstram que o diário não foi bem-sucedido, o participante A3 demonstra afinidade com o instrumento, interagindo com o leitor: "Você vai rir de mim se eu contar que o controle da Tv pendrive não quis funcionar hoje?"; "Então eu estou aqui, escrevendo para você (e sorrindo) em pleno domingo, só para contar que estou preparando a 'minha' aula de amanhã, e estou otimista, pois acredito que os alunos irão gostar" (A3). Na mesma linha, outro participante relata que utilizou o diário como um confidente, descrevendo suas frustações: “Eu não tinha mais aulas para elaborar e então decidi colocar minha experiência (quase frustrada!) neste diário" (A13).

Em outra perspectiva de avaliação do diário, realizada na terceira etapa da pesquisa, organizou-se as respostas dos seis participantes remanescentes no PIBID e as contribuições e dificuldades por eles citadas (Figura 4).

FIGURA 4: PERCEPÇÕES QUANTO À UTILIZAÇÃO DO DIÁRIO DE AULA

\section{Contribuições}

"Confrontar as práticas" (A2).

\begin{tabular}{|} 
"Ajuda a ter, mais disciplina mais organização com as atividades" \\
(A6). \\
"Proporciona uma evolução das aulas ou análises dos prós e \\
contras" (A12)
\end{tabular}

\section{Dificuldades}

"O único ponto que poderia ser tomado como negativo poderia ser a falta de tempo de sempre depois das aulas ter que escrever no diário" (A2).

\section{(A6)}

"O professor deve ter o costume de escrever nele $[\ldots]$ Eu nunca tive este costume" (A12).

"Apesar de achar um pouco chato ter que registrar as ocorrências" (A14).

"O prejuízo seria que com esse 'guia', a aula ficou muito presa àquilo, talvez porque eu me baseei demais no roteiro e esqueci de usar as ações do momento, para dar andamento a aula, ou também por falta de experiência de como lidar com as oportunidades que os próprios alunos dão para continuar a aula" (A13).

"[...] a utilização não me prejudicou em nenhum momento, só acrescentou mais na experiência docente" (A5).

Fonte: Elaboração própria.

Nessa figura identifica-se que as avaliações elencaram contribuições e dificuldades enfrentadas. Sobre essas avaliações, Galiazzi e Lindemann (2003) discorrem que as reflexões realizadas no diário promovem uma formação, configurando-se como um instrumento mediador de aprendizagem. A participante A5 ao responder acerca das dificuldades (quadro em amarelo) reforça que o diário só acrescentou a sua experiência na graduação. Diferentemente, os participantes relatam dificuldades como o fato de o diário ser trabalhoso 


\section{autêntica}

e a ausência de tempo para sua elaboração. Na interpretação de A13, o roteiro inicial (Figura 1) de alguma forma o prendeu.

Contudo, as contribuições citadas foram organização e percepções da própria prática e do desenvolvimento das atuações, características que demonstram indícios favoráveis à utilização do diário para o estímulo de reflexões iniciais. Esse start foi evidenciado nas descrições, análises e reflexões presentes nos diários, porém, como posto, exigem um empenho do licenciando.

De acordo com Zabalza (1994), a elaboração de diários contribui para que os professores transformem-se em investigadores de si próprios, primeiro como narradores e, posteriormente, como analistas críticos dos registros que elaboram. Assinalando ainda que o diário proporciona acesso ao mundo pessoal, à explicitação dos próprios dilemas, à posterior análise e avaliação do que pode ser reajustado, propiciando desenvolvimento profissional. Quando os participantes realizam os planejamentos e os estudos para ministrar suas primeiras aulas, apesar de toda a orientação, necessitam de autoanálise posterior ao processo. Quando criam um acervo para que possam observar e refletir sobre o que deu certo e/ou errado em suas atuações, passam a valorizar mais a experiência e dinamizar a sua própria formação. Assim, Zabalza (2004) enfatiza que o diário pode ser utilizado para conhecer o pensamento dos licenciandos/professores e mais concretamente identificar quais são seus dilemas práticos na ação, entendendo que os problemas são um conjunto de situações multifatoriais apresentadas ao professor no decorrer de sua atuação prática.

Desse modo, ressalta-se os indícios encontrados por este trabalho, tendo em vista o desenvolvimento do pensamento, dos escritores (pibidianos) sobre os processos de tomada de decisões ao enfrentar o início do trabalho docente, investigando mediante o diário suas experiências, por meio da reflexão sobre a ação (SCHÖN, 2000). 


\section{autêntica}

\section{CONSIDERAÇÕES FINAIS}

Considera-se que os estudos sobre professor reflexivo podem repercutir como melhoria na prática pedagógica dos professores se a reflexão for proposta desde a formação inicial. Porém, essa investigação somente foi possível após a superação de algumas dificuldades relacionadas às resistências iniciais dos participantes e à ausência de reflexão no processo de escrita. Apesar disso, a elaboração dos diários pelos participantes foi importante, inclusive para evidenciar falhas em sua utilização, tais como a ausência de seu preenchimento periódico e/ou a sua utilização descompromissada com o objetivo direcionado durante a pesquisa. Uma forma de driblar falhas na reflexão nos diários, no contexto do PIBID, é exigir avaliações periódicas desses instrumentos, recolhendo-os em determinados períodos para o direcionamento dessas reflexões e orientações pessoais. Não se pode afirmar, de forma contundente, que esse processo, em que a prática promove uma reflexão durante a ação, ocorre de forma generalizada, mas sim de maneira subjetiva devido à pluralidade de contextos presentes no PIBID. Essa reflexão pode e deve ser construída coletivamente para o compartilhamento de experiências e ideias, mas seu reflexo é pessoal, tendo em vista que o desenvolvimento do processo reflexivo e de construção dos saberes docentes, como evidenciam os diários, é um processo individual.

Sendo assim, são relevantes as contribuições que os diários podem ocasionar ao processo de formação de professores de Biologia. Assim, como explanam os principais autores acerca do uso dos diários, atestando que o simples fato de descrever as ações já proporciona um momento de reflexão, momento que estimula a mudança de concepção sobre a prática, partindo do acervo histórico ali construído. Nesse aspecto, o presente artigo sugere indícios favoráveis ao princípio de uma atitude reflexiva para a formação inicial de professores.

Paralelamente ressalta-se que esse elo entre ensino e pesquisa, em que o PIBID configura-se, é uma alternativa para desenvolver profissionais críticos, aulas dinâmicas e futuros professores dispostos a refletir sobre suas práxis continuamente. No Brasil, o PIBID entrou em seu oitavo ano de execução (2015), estimulando inúmeras pesquisas sobre seu contexto com o objetivo de identificar as contribuições dessa política pública para a formação e o ensino. Entretanto, atualmente o programa sofre um corte estrutural de dimensões alarmantes, que culmina para sua extinção nas IES, realizando nova quebra nas propostas de estimulo à formação de futuros professores. 


\section{autêntica}

\section{REFERÊNCIAS}

ALVES, N.N. de L. Amor à profissão, dedicação e o resto se aprende: significados da docência em Educação Infantil na ambiguidade entre a vocação e a profissionalização. In: REUNIÃO ANUAL DA ANPED, 29, 2006, Caxambu. Anais eletrônicos... Rio de Janeiro: Anped, 2006.

AMARAL, I.A. Metodologia do ensino de Ciências como produção social. São Paulo, maio 2006. Disponível em: < https://www.fe.unicamp.br/drupal/sites/www.fe.unicamp.br/files/pf/subportais/graduacao/proesf/ textos1.pdf>. Acesso em: 15 dez. 2016.

BARDIN, L. Análise de conteúdo. Lisboa: Edições 70, 1977.

BARREIROS, G.B. A formação de professores reflexivos no contexto PIBID: uma discussão sobre as modalidades e recursos didáticos no ensino de Biologia. Maringá: UEM, 2015. Dissertação (Mestrado em Educação) - Programa de Pós-Graduação em Educação, Faculdade de Educação, Universidade Estadual de Maringá, Maringá, 2015.

BARREIROS, G.B.; GIANOTTO, D.E.P. O diário de aula como registro reflexivo: uma investigação sobre os dilemas enfrentados durante o estágio supervisionado de biologia. Colloquium Humanarum, Presidente Prudente, v. 11, Edição especial, p. 951-959, 2014.

BOGDAN, R.; BIKLEN, S.K. Investigação qualitativa em educação. Porto: Porto Editora, 1991.

BRASIL. Edital de seleção pública de propostas de projetos de iniciação à docência voltados ao Programa Institucional de Iniciação à Docência - PIBID. Brasília: MEC, 2007.

CARDOSO, M.E. Identidade(s) e identidade(s) docente(s). Jornal de Políticas Educacionais, Curitiba, v. 4, n. 8, 2010.

CARVALHO, W. Biologia: o professor e a arquitetura do currículo. São Paulo: Articulação Universidade/Escola Ltda, 2000.

FERREIRA, M. O. V. Construção de identidades docentes: entre a vocação, as necessidades objetivas e os processos sociais. Educação, Porto Alegre, v. 34, n. 1, 2011.

FREITAS, D.; VILLANI, A. Formação de professores de ciências: um desafio sem limites. Investigações em Ensino de Ciências, Porto Alegre, v. 7, n. 3, 215-230, 2002. Disponível em: <https://www.if.ufrgs.br/cref/ojs/ index.php/ienci/article/view/559 >. Acesso em: 14 maio 2017.

GALIAZZI, M. do C.; LINDEMANN, H.O diário de estágio: da reflexão pela escrita para a aprendizagem sobre ser professor. Olhar de professor, Ponta Grossa, v. 6, n. 1, p. 135-150, 2003.

GARCÍA, C.M. Formação de professores: para uma mudança educativa. Porto: Porto Editora, 1999.

GARCIA, J. Indisciplina na escola: uma reflexão sobre a dimensão preventiva. Revista Paranaense de Desenvolvimento-RPD, Curitiba, n. 95, 101-108, 1999. 
GIANOTTO, D.E.P. Formação inicial de professores de biologia e o uso de computadores: uma análise de uma proposta de prática colaborativa. Bauru: Universidade Estadual Paulista, 2008. Tese (Doutorado em Educação). - Programa de Pós-Graduação em Educação, Faculdade de Filosofia e Ciências, Bauru, UNESP, 2008a.

GIANOTTO, D.E.P. A importância da elaboração e utilização do diário de aula na formação do professor. Texto elaborado para a disciplina Estágio Supervisionado I. Mimeo, 2008b.

GIANOTTO, D.E.P.; CARVALHO, F.A. de. Diário de aula e sua relevância na formação inicial de professores de Ciências Biológicas. REEC: Revista electrónica de enseñanza de las ciencias, n. 14, v. 2, p. 131-156, 2015.

GONÇALVES, F.P.et al. O diário de aula coletivo no estágio da Licenciatura em Química: dilemas e seus enfrentamentos. Química nova na escola, São Paulo, n. 30, p. 42-48, 2008.

KRASILCHIK, M. Prática de ensino de biologia. São Paulo: EDUSP, 2004.

LABURÚ, C.E.; ARRUDA, S. de M.; NARDI, R. Pluralismo Metodológico no Ensino de Ciências. Ciência \& Educação, Bauru, n. 9, v. 2, p. 247-260, 2003.

LIBÂNEO, J.C. Adeus professor, adeus professora? Novas exigências educacionais e profissão docente. São Paulo: Cortez, 2000.

LIBÂNEO, J.C.; OLIVEIRA, J.F. de; TOSCHI, M.S. Educação escolar: políticas, estrutura e organização. São Paulo: Cortez, 2003.

MARCELO, C. Pesquisa sobre a formação de professores. Revista Brasileira de Educação, Rio de Janeiro, v. 9, p. 51-75, 1998.

NÓVOA, A. Os professores e a sua formação. Lisboa: Dom Quixote, 1992.

NUNES, C.M.F. Saberes docentes e formação de professores: um breve panorama da pesquisa brasileira. Educação e Sociedade, Campinas, v. 22, n. 74, p. 27-42, 2001.

PANIZ, C. M. O diário da prática pedagógica e a construção da reflexividade na formação inicial de professores de Ciências biológicas da UFSM. Santa Maria: UFSM, 2007.Dissertação [Mestrado em Educação] -Programa de Pós-Graduação em Educação, Centro de Educação, Universidade Federal de Santa Maria, Santa Maria, 2007.

PEDROSO, S. M. D.; ROSSO, A. J. Diários de bordo: uma proposta para a prática de ensino e estágio supervisionado. In: REUNIÃO ANUAL DA ANPED SUL, 27, 2004, Caxambu. Anais... Rio de Janeiro: Anped, 2004.

PIETRO, R.G. O diário como instrumento para a formação permanente do professor de educação física. Lecturas, Educación y Deportes, Revista Digital, n. 9, v. 60, 2003.

PIMENTA, S.G. Saberes pedagógicos e atividade docente. São Paulo: Cortez, 2005.

PIMENTA, S.G.; GHEDIN, E. Professor reflexivo no Brasil: gênese e crítica de um conceito. São Paulo: Cortez, 2002. 


\section{autêntica}

PIMENTA, S.G.; LUCENA, M.S. Estágio e Docência. São Paulo: Cortez, 2004.

PORLÁN, R. El Maestro como Investigador en el Aula. Investigar para Conocer, Conocer para Enseñar. Revista Investigación en la Escuela, Sevilla, n. 1, p. 63-69, 1987.

PORLÁN, R.; MARTÍN, J. El diario del profesor: un recurso para la investigación en el aula. Sevilla: Díada, 1991.

SCHÖN, D.A. Educando o profissional reflexivo - um novo design para o ensino e a aprendizagem. Porto Alegre: Artimed, 2000.

SILVA, M.H.S.; DUARTE, M.C. O diário de aula na formação de professores reflexivos: resultados de uma experiência com professores estagiários de biologia/geologia. Revista Brasileira de Pesquisa em Educação em Ciências, Belo Horizonte, n. 1, v. 2, p. 73-84, 2001.

TARDIF, M. Saberes docentes e formação profissional. Petrópolis: Vozes, 2002.

TEIXEIRA, C.B. Formação de professores: tendências contemporâneas. Revista Eletrônica de Ciências da Educação, Campo Largo, n. 3, v. 1, 2004.

UEM - Universidade Estadual de Maringá. Edital n. ${ }^{\circ}$ 02/2009. Detalhamento de subprojeto de Licenciaturas: Ciências Biológicas. Maringá: CAPES/DEB, UEM, 2009.

UEM - Universidade Estadual de Maringá. Edital n. ${ }^{\circ}$ 061/2013. Detalhamento de subprojeto de Licenciaturas: Ciências Biológicas. Anexo I. Maringá: CAPES/DEB, UEM, 2013.

ZABALZA, M.A. Diários de aula: contributo para o estudo dos dilemas práticos dos professores. Porto: Porto Editora, 1994.

ZABALZA, M.A. Diários de aula: um instrumento de pesquisa e desenvolvimento profissional. Porto Alegre: Mediação, 2004.

ZEICHNER, K.M. Uma análise crítica sobre a "reflexão" como conceito estruturante na formação docente. Educação e Sociedade, Campinas, n. 29, v. 103, p. 535-554, 2008. 